\title{
Ocean Acidification and Direct Interactions Affect Coral, Macroalga, and Sponge Growth in the Florida Keys
}

\author{
Heather N. Page ${ }^{1,2, *}$, Clay Hewett ${ }^{1,3}$, Hayden Tompkins ${ }^{1,4}$ and Emily R. Hall ${ }^{5}$ (D) \\ 1 International Center for Coral Reef Research and Restoration, Mote Marine Laboratory, 24244 Overseas \\ Highway, Summerland Key, FL 33042, USA; chewett@jacksonville.edu (C.H.); \\ hayden.tompkins@rsmas.miami.edu (H.T.) \\ 2 Sea Education Association, 171 Woods Hole Road, Falmouth, MA 02540, USA \\ 3 Marine Science Research Institute, Jacksonville University, 2800 University Blvd N, \\ Jacksonville, FL 32211, USA \\ 4 Rosenstiel School of Atmospheric and Marine Science, University of Miami, 4600 Rickenbacker Causeway, \\ Miami, FL 33149, USA \\ 5 Mote Marine Laboratory, 1600 Ken Thompson Parkway, Sarasota, FL 34236, USA; emily8@mote.org \\ * Correspondence: hpage@sea.edu
}

Citation: Page, H.N.; Hewett, C.; Tompkins, H.; Hall, E.R. Ocean Acidification and Direct Interactions Affect Coral, Macroalga, and Sponge Growth in the Florida Keys. J. Mar. Sci. Eng. 2021, 9, 739. https:// doi.org/10.3390/jmse9070739

Academic Editor: Ernesto Weil

Received: 21 May 2021

Accepted: 1 July 2021

Published: 4 July 2021

Publisher's Note: MDPI stays neutral with regard to jurisdictional claims in published maps and institutional affiliations.

Copyright: (c) 2021 by the authors. Licensee MDPI, Basel, Switzerland. This article is an open access article distributed under the terms and conditions of the Creative Commons Attribution (CC BY) license (https:// creativecommons.org/licenses/by/ $4.0 /)$

\begin{abstract}
Coral reef community composition, function, and resilience have been altered by natural and anthropogenic stressors. Future anthropogenic ocean and coastal acidification (together termed "acidification") may exacerbate this reef degradation. Accurately predicting reef resilience requires an understanding of not only direct impacts of acidification on marine organisms but also indirect effects on species interactions that influence community composition and reef ecosystem functions. In this 28-day experiment, we assessed the effect of acidification on coral-algal, coral-sponge, and algal-sponge interactions. We quantified growth of corals (Siderastrea radians), fleshy macroalgae (Dictyota spp.), and sponges (Pione lampa) that were exposed to local summer ambient (603 $\mu \mathrm{atm})$

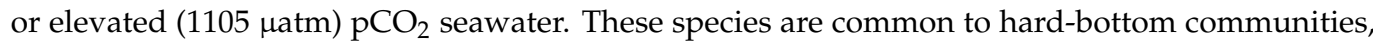
including shallow reefs, in the Florida Keys. Each individual was maintained in isolation or paired with another organism. Coral growth (net calcification) was similar across seawater $\mathrm{pCO}_{2}$ and interaction treatments. Fleshy macroalgae had increased biomass when paired with a sponge but lost biomass when growing in isolation or paired with coral. Sponges grew more volumetrically in the elevated seawater $\mathrm{pCO}_{2}$ treatment (i.e., under acidification conditions). Although these results are limited in temporal and spatial scales due to the experimental design, they do lend support to the hypothesis that acidification may facilitate a shift towards increased sponge and macroalgae abundance by directly benefiting sponge growth which in turn may provide more dissolved inorganic nitrogen to macroalgae in the Florida Keys.
\end{abstract}

Keywords: climate change; seawater $\mathrm{pH}$; coral-algal competition; coral-sponge interaction; sponge loop hypothesis

\section{Introduction}

Ocean acidification is the decrease in seawater $\mathrm{pH}$ and carbonate $\left(\mathrm{CO}_{3}{ }^{2-}\right)$ ions following oceanic uptake of anthropogenically generated atmospheric carbon dioxide $\left(\mathrm{CO}_{2}\right)$. Open ocean surface seawater $\mathrm{pH}$ is projected to decrease up to 0.29 units below present-day conditions by 2081-2100 under the most extreme representative concentration pathway (RCP) for greenhouse gases (RCP 8.5) [1]. This long-term acidification may be exacerbated across temporal scales in coastal environments in response to terrestrial influences [2] and other biogeochemical processes [3]. The changes in seawater chemistry from ocean and coastal acidification (herein termed "acidification") is predicted to facilitate shifts in coral reef communities away from coral dominance in favor of non-calcifying macroalgae and sponges [4]. This prediction is largely based on the responses of individuals to high 
seawater $\mathrm{pCO}_{2}$ in experimental settings and observations of benthic communities spanning natural $\mathrm{pH}$ gradients near $\mathrm{CO}_{2}$ seeps. Net calcification of corals generally (although not always) decrease under exposure to acidification [5] while, in contrast, non-calcifying macroalgae and reef sponges maintain or accelerate their growth rates when exposed to elevated seawater $\mathrm{pCO}_{2}[6-9]$.

Benthic community composition on coral reefs, however, is influenced by a variety of ecological and biogeochemical processes including species interactions, local environmental effects (e.g., nutrient input), and global climate change. Therefore, accurate predictions of future coral reef community composition require understanding not just the responses of individuals to acidification but also the indirect effects of changing carbonate chemistry on ecological processes influencing community structure [10]. Species interactions occurring on coral reefs could modify the responses of individuals to acidification. For example, ocean acidification accelerated tissue mortality rates for corals in direct contact with non-calcifying macroalgae [11,12]. Similarly, Campbell et al. [13] observed that low pH exacerbated negative effects of Stypopodium zonale on Porites coral larvae settlement on crustose coralline algae substrate.

Dominant benthic taxa on coral reefs interact through a variety of mechanisms (for reviews, see [14-16]). These mechanisms include both direct and indirect interactions. For example, excess photosynthate (i.e., dissolved organic carbon) produced by autotrophs (e.g., corals and macroalgae) is consumed by some sponges and planktonic bacteria [16-19]. Sponges, in turn, shed tissue as particulate organic carbon which feeds detritivores $[17,20]$. In general, encrusting and excavating sponges have higher tissue shedding rates compared to sponges with emergent morphologies [21]; therefore, the prevalence of this sponge loop on Caribbean reefs depends on the sponge community present. Sponge exudate can be enriched in dissolved inorganic nitrogen, depending on the abundance of microbial symbionts [22,23], and these nutrients may be beneficial for macroalgae [24]. The resulting potentially favorable conditions for sponge and macroalga species may then create a positive feedback loop with each taxon stimulating the growth of the other. In contrast, fleshy algae may cause coral mortality directly through abrasion and/or indirectly by fueling the growth of harmful pathogens thus leading to substantially higher coral mortality $[25,26]$. Sponges also may impact coral growth and survivorship through overgrowth and/or bioerosion [27-29].

Acidification may indirectly alter the magnitude and outcome of each of these interactions, ultimately influencing the relative abundance of dominant benthic taxa within reef communities and ecosystem processes. For example, sponge bioerosion can be enhanced under acidification [6,30], ultimately negatively impacting net carbonate accretion on reefs. Understanding the result of these interactions may be especially important for reefs that already have lower coral cover and higher abundance of other benthic organisms [31]. In the Caribbean region, coral cover has declined significantly over the past few decades [32,33] due to a variety of local, regional, and global stressors [34]. The benthic community of coral reefs located in the Florida Keys is dominated by macroalgae, octocorals, scleractinian corals, and sponges (Florida Fish and Wildlife Commission, CREMP, data accessed on 12 October 2020).

Therefore, in the present study, we investigated the independent and combined effects of direct contact (i.e., interaction) and acidification on the growth of three common Florida Keys species including a scleractinian coral (Siderastrea radians), fleshy macroalga (Dictyota spp.), and encrusting sponge (Pione lampa). These species are prevalent in shallow hard-bottom communities and are likely to persist on shallow reefs in the future due to observed tolerance for environmental variability $[35,36]$ and lower susceptibility to stony coral tissue loss disease [37]. We hypothesized: (1) coral net calcification decreases under acidification conditions, (2) this decrease is greater when corals are in contact with competitors (i.e., macroalgae and sponges) under acidification, and (3) macroalga and sponge growth increase under acidification. To test these hypotheses, a 28-day experiment was conducted using the Climate and Acidification Ocean Simulator (CAOS) at Mote 
Marine Laboratory's Elizabeth Moore International Center for Coral Reef Research and Restoration, located in Summerland Key, Florida. The results of this study highlight the importance of considering species interactions when predicting the response of coral reefs to acidification in the Florida Keys.

\section{Methods}

\subsection{Specimen Collection}

Specimens were collected from within the Florida Keys National Marine Sanctuary under permit FKNMS-2018-075. Encrusting P. lampa sponges $(n \approx 5)$ and Dictyota spp. algae thalli ( 115 g total wet weight) were collected from a patch reef (water depth: $6 \mathrm{~m}$ ) located near Mote Marine Laboratory's offshore coral nursery, south of Summerland Key. Coral colonies $(n=24)$ were rescued from a dock piling (water depth: $1-2 \mathrm{~m}$ ) located in Key West. All specimens (sponges, algae, and corals) were immediately transported to Summerland Key, Florida, where they were placed in the CAOS outdoor experimental facility to acclimate in running seawater. We were unable to collect 24 individual sponges of similar sizes, so after $72 \mathrm{~h}$ of acclimating to ambient seawater, larger sponges were fragmented into smaller pieces similar in size to smaller sponges (Supplemental Table S1); sizes were estimated visually. All specimens continued to acclimate in ambient seawater for an additional 7 days to allow for recovery of fragmented sponges (i.e., new growth covering fragmented edges and open oscula indicating active pumping of seawater through sponge tissues). Before starting the experiment, corals, algae, and sponges were acclimated to target $\mathrm{pH}$ levels which were gradually reached over a period of four days.

\subsection{Experimental System (CAOS) and Design}

Seawater was pumped from the Atlantic side of the Florida Keys through a sand filter and a $20 \mu \mathrm{m}$ particle filter into six large reservoir tanks that were independently temperature- and pH-regulated using Walchem Series W900 (Iwaki America, Inc., Hopping Brook Park Holliston, MA, USA) controllers. This monitoring system includes temperature and $\mathrm{pH}$ probes that measure seawater conditions every $2 \mathrm{~s}$. The $\mathrm{pH}$ electrodes were calibrated against three National Bureau of Standards (NBS) buffers weekly. Reservoir tanks contained one of two seawater $\mathrm{pH}$ treatments representing ambient conditions and high $\mathrm{pCO}_{2}$ /low $\mathrm{pH}$ conditions. We targeted a $\mathrm{pH}$ offset of -0.3 below ambient, the predicted decline by 2081 to 2100 under RCP 8.5 [1]. The Walchem controllers regulated Venturi pumps and solenoids that were triggered to add $\mathrm{CO}_{2}$ whenever $\mathrm{pH}$ was 0.01 above the target value. Two reservoir tanks were used at any given time (i.e., one tank per $\mathrm{pH}$ treatment), and we rotated the two reservoir tanks in use every two weeks.

This well-mixed seawater flowed into $9.5 \mathrm{~L}$ flow-through aquaria that were housed within outdoor shaded, temperature-controlled raceways ( $n=28$ aquaria per raceway). Light levels within the raceways were measured twice a week at the same time (1400 EDT) using a LI-COR (LI-1500G Light Sensor Logger with a LI-192SA underwater quantum sensor) and averaged ( \pm 1 standard deviation, sd) $301 \pm 205 \mu \mathrm{E} \mathrm{m}^{-2} \mathrm{~s}^{-1}$. Temperature was controlled using dual heat exchange systems. Each aquarium received either ambient or acidified seawater at flow rates of seven $\mathrm{mL} \mathrm{s}^{-1}$. Small fountain pumps were used to ensure seawater was well-mixed within the aquaria.

We used a factorial design with each aquarium receiving one of two $\mathrm{pCO}_{2}$ treatments (ambient or elevated) and one of seven interaction treatments (i.e., 14 combinations total; $n=$ four replicates for each combination). The interaction treatments included: (1) Control (no specimen), (2) Coral only, (3) Macroalgae only, (4) Sponge only, (5) Coral-Macroalgae pair, (6) Coral-Sponge pair, and (7) Macroalgae-Sponge pair. Individual replicates were a single coral colony, small clump of macroalgae $(4.76 \pm 0.01 \mathrm{~g})$ held together using a cable tie, or sponge fragment. Only one individual or pair was included in each aquarium. Specimens were elevated off the bottom using egg crate stands. Pairs were set up with organisms touching one another (i.e., in direct contact) (Supplemental Figure S1). Specimens were exposed to the $\mathrm{pCO}_{2}$ and interaction treatments for 28 days. This ex- 
perimental duration is similar to previous studies documenting impacts of acidification on coral-algal interactions [11,12]. We did not feed the corals and sponges throughout the 28 days because feeding has the potential to modify the physiological responses of organisms to stressors $[38,39]$ and the carbonate chemistry of the experimental tanks (i.e., through increased respiration). Throughout the experiment, coral, sponge, and macroalga health (e.g., tissue color) were monitored daily and aquaria were cleaned bi-weekly.

\subsection{Monitoring Environmental Conditions}

Multiple temperature and $\mathrm{pH}$ probes continuously monitored several experimental aquaria $(n=8)$ using the Walchem monitoring systems. Probes were cleaned of epiphytes and calibrated weekly. The $\mathrm{pH}$ electrodes were calibrated against three NBS buffers. Seawater temperature $\left( \pm 0.2{ }^{\circ} \mathrm{C}\right)$, salinity $\left( \pm 1.0 \%\right.$ of the reading), and $\mathrm{pH}_{\mathrm{NBS}}( \pm 0.2)$ of all reservoir tanks $(n=2)$ and experimental aquaria $(n=56)$ were monitored daily during mid-morning using a YSI Professional Plus handheld multiparameter instrument (Xylem Inc., Rye Brook, NY, USA). This instrument was calibrated for salinity weekly using a conductivity standard and for $\mathrm{pH}$ daily using NBS buffers. Once a week, seawater samples for laboratory analysis of carbonate chemistry were collected in $120 \mathrm{~mL}$ borosilicate glass bottles following best practices in seawater $\mathrm{CO}_{2}$ chemistry sampling [40]. Samples were collected from each reservoir tank and random subset $(n=28)$ of experimental aquaria during the morning (0900-1030 local time). We preserved seawater samples with a saturated solution of mercuric chloride $\left(\mathrm{HgCl}_{2}\right)$ to halt biological activity that may alter seawater carbonate chemistry and stored samples at $4{ }^{\circ} \mathrm{C}$ until analysis.

Seawater samples were analyzed for dissolved inorganic carbon (DIC) and total alkalinity (TA) following best practices [40]. DIC was measured using an Apollo SciTech DIC Analyzer (Model AS-C3) equipped with a LI-COR LI-7000 gas analyzer. TA titrations were performed using a Metrohm 905 PC1 Titrando with 800 Dosino dosing apparatus. Certified Reference Standards for Seawater $\mathrm{CO}_{2}$ Chemistry from the Dickson Laboratory (Scripps Institution of Oceanography, UCSD) were used to ensure good instrument performance. Accuracy and precision of the instruments were less than four $\mu \mathrm{mol} \cdot \mathrm{kg}^{-1}$ for DIC and TA measurements. The remainder of the carbonate chemistry system was constrained using the R package seacarb [41] with K1 and K2 constants from Lueker et al. [42].

\subsection{Coral, Macroalgae, and Sponge Growth}

The buoyant weight of corals, wet weight of macroalgae, and volume of sponges ( $n=24$ per species) were measured at the beginning and end of the experiment ( $n=28$ days). Coral growth (g) was measured using the buoyant weight technique [43]. To calculate buoyant weight, coral skeletal density was assumed to be $2.93 \mathrm{~g} \mathrm{~cm}^{-3}$ which is the density of aragonite $\left(\mathrm{CaCO}_{3}\right)$. Macroalgae growth $(\mathrm{g})$ was quantified by blotting off excess water and measuring wet weight. Sponge growth $\left(\mathrm{cm}^{3}\right)$ was measured by recording the volume of seawater displaced when submerged. For coral buoyant weight and sponge volume calculations, seawater temperature and salinity were recorded hourly to calculate seawater density.

\subsection{Statistical Analyses}

A two-way analysis of variance (ANOVA) was used to test the individual (i.e., main) and combined (i.e., interactive) effects of seawater $\mathrm{pCO}_{2}$ (2 levels) and interaction (3 levels) on the growth of corals, macroalgae, and sponges. Data met the assumptions for independence, normality (qqplots and Shapiro-Wilk Tests), and homogeneity of variance (Levene's Test; car package [44]). Statistical analyses were performed and figures were created using RStudio v1.2.5033 [45]. Growth data are reported as mean \pm 1 standard error, se, and were plotted using ggplot2 package [46]. 


\section{Results}

\subsection{Environmental Conditions}

All experimental aquaria exhibited similar seawater temperature and salinity while seawater $\mathrm{pCO}_{2}$ and $\mathrm{pH}_{\mathrm{T}}$ differed (Table 1; Supplemental Table S2). Temperatures (mean $\pm 1 \mathrm{sd}$ ) were $27.1 \pm 0.3{ }^{\circ} \mathrm{C}$ and $27.2 \pm 0.3{ }^{\circ} \mathrm{C}$ for ambient and elevated $\mathrm{pCO}_{2}$ treatments, respectively. Salinity was slightly variable over time due to occasional rain showers throughout the experiment but similar across treatments (37.61 \pm 1.37 for ambient $\mathrm{pCO}_{2}$ treatment and $37.54 \pm 1.31$ for elevated $\mathrm{pCO}_{2}$ treatment). Seawater $\mathrm{pCO}_{2}$ was $603 \pm 88 \mu \mathrm{atm}$ and $1105 \pm 89 \mu \mathrm{atm}$ for ambient and elevated $\mathrm{pCO}_{2}$ treatments, respectively. This led to a seawater $\mathrm{pH}$ offset of approximately 0.23 units; ambient $\mathrm{pH}_{\mathrm{T}}$ was $7.86 \pm 0.05$ while $\mathrm{pH}_{\mathrm{T}}$ of the elevated $\mathrm{pCO}_{2}$ treatment was $7.63 \pm 0.04$. These are conservative estimates of mean seawater $\mathrm{pCO}_{2}$ and $\mathrm{pH}$ of the aquaria since measurements were taken in the morning prior to peak $\mathrm{pH}$ values during midday. However, the ambient seawater $\mathrm{pCO}_{2}$ and $\mathrm{pH}_{\mathrm{T}}$ reported here do match summer in situ conditions measured for coastal waters in southern Florida including Cheeca Rocks [47], Florida Bay [48,49] and Florida Keys inlets [50].

Table 1. Environmental conditions and carbonate chemistry (mean $\pm 1 \mathrm{sd}$ ) of experimental system seawater from measurements taken during morning. Temperature and Salinity were measured daily in both reservoir tanks $(n=2)$ and all experimental aquaria $(n=56)$. Dissolved inorganic carbon (DIC) and total alkalinity (TA) were measured every seven days in both reservoir tanks $(n=2)$ and half of the experimental aquaria $\left(n=14\right.$ per $\mathrm{pCO}_{2}$ treatment). The remaining variables were calculated from T, S, DIC, and TA.

\begin{tabular}{|c|c|c|c|c|c|c|c|}
\hline & $\mathrm{T}\left({ }^{\circ} \mathrm{C}\right)$ & Salinity & DIC $\left(\mu \mathrm{mol} \mathrm{kg}{ }^{-1}\right)$ & TA $\left(\mu \mathrm{mol} \mathrm{kg}{ }^{-1}\right)$ & $\mathrm{pH}_{\mathrm{T}}$ & $\mathrm{pCO}_{2}(\mu \mathrm{atm})$ & $\Omega_{\text {Arag. }}$ \\
\hline \multicolumn{8}{|l|}{ Reservoir Tanks } \\
\hline Ambient $\mathrm{pCO}_{2}$ & $28.6 \pm 0.1$ & $37.74 \pm 1.74$ & $1953 \pm 56$ & $2169 \pm 73$ & $7.82 \pm 0.04$ & $676 \pm 65$ & $2.46 \pm 0.28$ \\
\hline Elevated $\mathrm{pCO}_{2}$ & $28.8 \pm 0.2$ & $37.60 \pm 1.52$ & $2040 \pm 67$ & $2152 \pm 70$ & $7.58 \pm 0.02$ & $1263 \pm 76$ & $1.52 \pm 0.09$ \\
\hline \multicolumn{8}{|c|}{ Experimental Aquaria } \\
\hline Ambient $\mathrm{pCO}_{2}$ & $27.1 \pm 0.3$ & $37.61 \pm 1.37$ & $1926 \pm 58$ & $2149 \pm 63$ & $7.86 \pm 0.05$ & $603 \pm 88$ & $2.50 \pm 0.24$ \\
\hline Elevated $\mathrm{pCO}_{2}$ & $27.2 \pm 0.3$ & $37.54 \pm 1.31$ & $2021 \pm 56$ & $2144 \pm 67$ & $7.63 \pm 0.04$ & $1105 \pm 89$ & $1.59 \pm 0.18$ \\
\hline
\end{tabular}

\subsection{Growth Responses of Corals, Macroalgae, and Sponges}

There were no combined effects of seawater $\mathrm{pCO}_{2}$ and interaction treatments on the growth of corals, macroalgae, or sponges (Table 2; Figure 1). Coral growth was similar across treatments with no statistically significant effects of seawater $\mathrm{pCO}_{2}$ or direct contact (i.e., interaction) with macroalgae and sponges. The total growth of the corals over the 28-day experiment ranged from $0.75 \pm 0.54 \mathrm{~g}$ (Ambient $\mathrm{pCO}_{2}$ Coral-Sponge treatment) to $1.75 \pm 0.47 \mathrm{~g}$ (Elevated $\mathrm{pCO}_{2}$ Coral-Sponge treatment). The change in macroalgae biomass was unaffected by seawater $\mathrm{pCO}_{2}$, but there was a statistically significant main effect of interaction treatment on growth $\left(\mathrm{F}_{2,18}=7.523, p=0.004\right)$; macroalgae lost biomass when growing in isolation $(-0.89 \pm 0.46 \mathrm{~g})$ or paired with corals $(-1.21 \pm 0.22 \mathrm{~g})$ but gained biomass when paired with a sponge $(1.29 \pm 0.65 \mathrm{~g})$. Sponges had increased growth under elevated seawater $\mathrm{pCO}_{2}$ conditions $\left(\mathrm{F}_{2,18}=21.911, p<0.001\right)$. Sponge growth was $-0.19 \pm 0.08 \mathrm{~cm}^{3}$ and $0.29 \pm 0.05 \mathrm{~cm}^{3}$ for ambient and elevated $\mathrm{pCO}_{2}$ treatments, respectively. Interaction treatment had no statistically significant effect on the change in sponge bioviolume. 
Ambient $\mathrm{pCO}_{2}$ Elevated $\mathrm{pCO}_{2}$

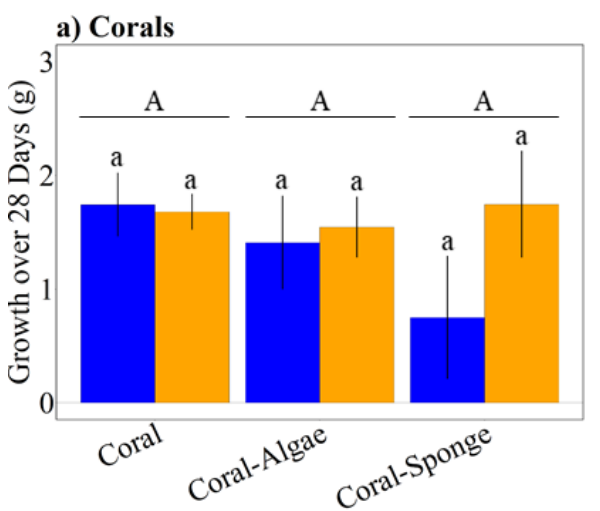
b) Macroalgae

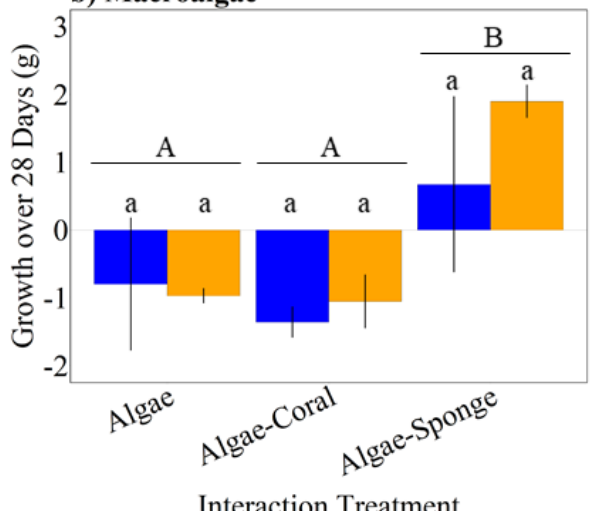

c) Sponges

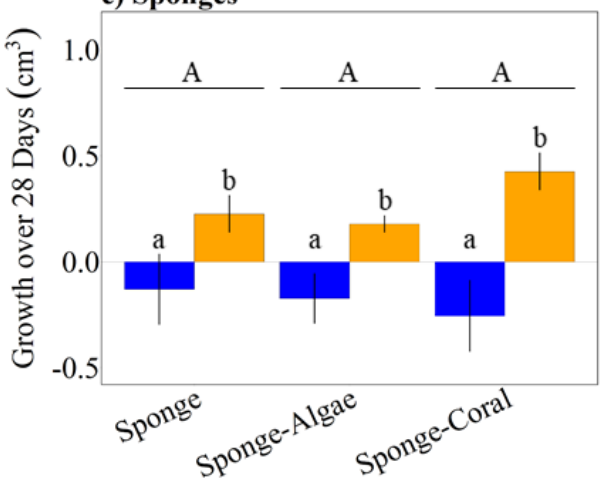

Figure 1. Growth responses (mean \pm 1 se) of (a) corals, (b) macroalgae, and (c) sponges exposed to ambient $\mathrm{pCO}_{2}$ (blue) and elevated $\mathrm{pCO}_{2}$ (orange) treatments over 28 days. Data were statistically analyzed with a two-way analysis of variance (ANOVA). The small letters $(\mathrm{a}, \mathrm{b})$ represent statistical differences between $\mathrm{pCO}_{2}$ treatments, and the capitalized letters $(\mathrm{A}$, B) represent statistical differences between interaction treatments. The full results of the two-way ANOVA are presented in Table 2.

Table 2. Statistical analyses of coral, macroalga, and sponge growth in response to seawater $\mathrm{pCO}_{2}$ and interaction treatment. * indicates statistical significance.

\begin{tabular}{ccccc}
\hline Organism & Treatments & df & F-Value & $p$-Value \\
\hline Coral & Seawater $\mathrm{pCO}_{2}$ & 1 & 0.749 & 0.487 \\
& Interaction & 2 & 1.327 & 0.264 \\
Macroalgae & Seawater $\mathrm{pCO}_{2} \times \mathrm{Interaction}$ & 2 & 1.107 & 0.352 \\
& Seawater $\mathrm{pCO}_{2}$ & 1 & 0.630 & 0.438 \\
Sponge & Interaction & 2 & 7.523 & 0.004 \\
& Seawater $\mathrm{pCO}_{2} \times \mathrm{Interaction}$ & 2 & 0.516 & 0.605 \\
& Seawater $\mathrm{pCO}_{2}$ & 1 & 21.911 & $<0.001$
\end{tabular} *

\section{Discussion}

While there are abundant data describing the responses of individuals to acidification, fewer studies have examined the effects of acidification on species interactions, despite the importance of ecological processes to coral reef community structure, ecosystem function, and resilience. We tested three hypotheses related to the effects of acidification and species interaction on growth of corals, macroalgae, and sponges. Although we expected decreased net calcification of corals and increased macroalgae and sponge growth under elevated seawater $\mathrm{pCO}_{2}$, only sponges responded with increased biovolume. Macroalgae, however, only grew when in direct contact with sponges compared to growing in isolation or paired with corals. The results of this study provide additional insight into the growth response of individuals when exposed to acidification and forced to interact with other organisms via direct contact.

Although corals typically have decreased growth and net calcification under ocean acidification [5], S. radians is well-known for high tolerance to environmental perturbations including low salinity [36] and high sedimentation [35]. In ecological surveys of benthic communities surrounding submarine springs discharging acidified seawater, $S$. radians was one of three coral species found in regions with seawater $\mathrm{pH}$ under 7.25, which is greater than the expected change by 2100 in open ocean surface waters [1], and coral area was similar across seawater $\mathrm{pH}$ gradients [51]. Although these ecological surveys suggest resistance to ocean acidification by S. radians, sublethal effects (i.e., on calcification rates, skeletal density, or other physiological processes) of elevated seawater $\mathrm{pCO}_{2}$ have not 
been assessed. Furthermore, the coral populations studied at seeps have been exposed to acidification and co-varying environmental parameters over longer time periods than laboratory experiments. Indeed, net calcification of $S$. radians decreases in response to elevated seawater $\mathrm{pCO}_{2}$ in experimental settings, both laboratory and in situ, in the Florida Keys [52,53].

In the present study, $S$. radians maintained net calcification under short-term exposure to elevated seawater $\mathrm{pCO}_{2}$ which resulted in a $\mathrm{pH}$ decline of 0.23 below ambient conditions. Environmental history of these coral colonies may have influenced their resistance to acidification [54,55]. Siderastrea radians colonies were collected from a shallow environment that contained an abundance of decaying organic matter; it is possible this area experiences episodic or chronic elevated seawater $\mathrm{pCO}_{2}$ in response to the dead algae and seagrasses that accumulate in this area (i.e., promoting net respiration [3]). This extremely shallow site $(<3 \mathrm{~m})$ also is likely exposed to high diurnal fluctuations in seawater $\mathrm{pH}$ and $\mathrm{pCO}_{2}$ [56] which could enhance the ability of corals to cope with ocean acidification [54,55]. Therefore, the coral colonies used in this experiment may have been acclimated to short-term exposure to acidification of similar magnitude shown here ( $\mathrm{pH}$ offset: approximately -0.23 ).

In contrast to corals, fleshy macroalgae typically exhibit maintained or increased growth when exposed to elevated seawater $\mathrm{pCO}_{2}$ and reduced $\mathrm{pH}[7,8,57]$. The variability in growth responses of fleshy macroalgae to ocean acidification may be related to their method of dissolved inorganic carbon uptake (i.e., $\mathrm{CO}_{2}$ diffusion or bicarbonate uptake via carbon concentrating mechanism, CCMs) and whether they are currently carbon-limited (i.e., affinity for dissolved inorganic carbon). Additionally, some species can down-regulate their CCMs to reduce energy expenditure. In general, carbon-limited macroalgae with no or downregulated CCMs experience increased growth rates under ocean acidification [58]. Macroalgae that are not carbon limited and solely rely on CCMs for carbon uptake have no change in growth rates under acidification [58]. Brown macroalgae, including Dictyota species, contain CCMs that can be utilized for inorganic carbon uptake [7].

In the present study, the change in biomass for Dictyota spp. used in this study was not significantly affected by seawater $\mathrm{pCO}_{2}$ which indicates they likely relied on CCMs throughout the experiment. Algae lost slight biomass in four out of six treatments. Light limitation could have inhibited algal growth. A separate field study during August 2018 [59] recorded, on average, higher daily maximum light levels near the site where algae were collected. However, we believe nutrient limitation is more likely contributing to the loss in algal biomass since contact with sponges led to growth; encrusting sponges likely produce dissolved inorganic nitrogen that algae can utilize for growth [24]. Regardless of whether algae had increased or decreased biomass, there was no significant influence of seawater $\mathrm{pCO}_{2}$ on growth. This is consistent with other studies that show similar growth rates under ambient and elevated $\mathrm{pCO}_{2}$ treatments for Dictyota species $[8,60,61]$.

Although sponge prevalence on Caribbean reefs have been increasing over recent decades [29,33,62], they remain one of the most understudied reef taxa with respect to climate change responses [63]. In general, sponges that range across geographic locations, morphologies, and feeding strategies (phototrophic vs. heterotrophic) appear to tolerate short-term ocean acidification as evidenced by: (1) unaltered or reduced mortality across life stages $[9,64],(2)$ maintained or increased growth [6,64-66], and (3) high abundance near $\mathrm{CO}_{2}$ seeps $[67,68]$. Our results support this previous body of literature, which includes experimental durations ranging from twelve days to several months, by showing sponge growth only when exposed to elevated seawater $\mathrm{pCO}_{2}$ for 28 days. Altered microbiome community composition may enhance sponge tolerance to ocean acidification $[66,68]$, though there is also evidence showing no change [69] or destabilization [70] of microbiomes in some sponge species. Sponge tolerance could also be linked to changes in tissue lipid or fatty acid composition as observed for sponges experiencing temperature stress [71]. While there has been considerable effort to quantify physiological responses of excavating sponges to acidification [72,73], more research is needed to underpin the physiological 
mechanisms driving encrusting and emergent sponge growth responses to changing ocean carbonate chemistry.

Few experiments have documented the effects of acidification on interactions between corals, macroalgae, and sponges. In fact, coral-algal competition experiments in combination with elevated seawater $\mathrm{pCO}_{2}$ are limited to a single coral species found on the Great Barrier Reef (Acropora intermedia). Diaz-Pulido et al. [11] observed 100\% coral mortality after three weeks of direct contact with Lobophora papenfusii, a fleshy brown macroalga, under elevated seawater $\mathrm{pCO}_{2}(1140 \mathrm{ppm})$ with lower mortality rates in ambient seawater $\mathrm{pCO}_{2}$. In a similar experiment, Del Monaco et al. [12] noted increased coral tissue necrosis under ocean acidification when in contact with three macroalgae species for 25 days. Although macroalgae can compete with corals using several physical and chemical strategies [14], both studies suggested increased allelopathy under ocean acidification due to minimal effects of algal mimics on coral survivorship. However, only Canistrocarpus (= Dictyota) cervicornis had increased allelopathy that led to decreased effective quantum yield of corals under high seawater $\mathrm{pCO}_{2}(936 \mathrm{ppm})$ [12]. In contrast to these results, Brown et al. [74] reported no main or interactive effects of ocean acidification and direct contact with a calcifying macroalga Halimeda heteromorpha on coral survivorship or net calcification during eight-week experiments conducted in summer and winter months. Likewise, S. radians from the Florida Reef Tract appear to be resistant to coral-algal competition even under ocean acidification. However, there may have been other physiological impacts not quantified in this study.

Many experiments ranging from three days to twenty weeks suggest acidification may lead to increased sponge bioerosion rates [6,75-77], consequently leading to decreased net calcification of living corals [78] and increased calcium carbonate $\left(\mathrm{CaCO}_{3}\right)$ dissolution of dead corals [76,78-80]. Here, we also show that a non-photosynthetic encrusting/excavating sponge adjacent to $S$. radians does not impact net calcification of the coral. Sponge-coral interactions, however, occur across sponge morphologies. As sponges become more prevalent on Caribbean reefs [29,33,62], we would expect more coral-sponge interactions to occur through direct contact. Therefore, additional research also is needed to understand how a variety of sponge species and morphologies may influence coral settlement and growth, two ecological processes influencing reef resilience to environmental perturbations [81], under future acidification and co-occurring environmental changes $[6,72,73,77,82]$.

Sponges play important roles in biogeochemical cycling on coral reefs through physiological and microbially-mediated processes [83]. Interestingly, direct contact with corals and macroalgae did not enhance sponge growth; many encrusting and boring sponge species, which often have high microbial abundance, rely on dissolved organic carbon production by reef autotrophs $[17,84]$. Low photosynthetic and/or carbon fixation rates by corals and macroalgae (not measured in this study) may explain the lack of influence on sponge growth. It is also possible P. lampa does not rely on autotroph-produced dissolved organic matter for carbon, although this seems unlikely given the trends observed for other encrusting and excavating sponges $[17,84]$.

Sponges also can contribute to nitrogen cycling on reefs since their microbial symbionts are capable of nitrogen fixation (i.e., $\mathrm{N}_{2}$ to $\mathrm{NH}_{3}$ ) and nitrification $\left(\mathrm{NH}_{3}\right.$ to $\mathrm{NO}_{2}$ and $\mathrm{NO}_{3}$ ). In this study, the presence of sponges did influence macroalgae growth; direct contact with sponges resulted in macroalgae biomass increase over time, counteracting autogenic biomass loss observed in other interaction treatments. Sponges may have facilitated macroalgae growth through the production of dissolved inorganic nitrogen [16] which can be elevated in sponge exudate compared to surrounding seawater on reefs $[22,23,85]$ depending on microbial abundance and community composition within sponge tissues [83]. When comparing $\delta^{15} \mathrm{~N}$ values of Dictyota species growing inside and outside of sponge oscular chambers at Conch Reef (Florida, USA), Silbiger [24] observed lower $\delta^{15} \mathrm{~N}$ in Dictyota growing inside sponges, supporting the hypothesis that sponge-produced nitrate may facilitate seaweed proliferation on reefs $[16,23]$. 
Ecosystem processes play important roles in shaping the community structure of coral reefs and, consequently, reef resilience to environmental change. Projections of future coral reef health, therefore, need to integrate impacts across ecological scales [10]. This includes improving our understanding of how species interactions can modify individual responses to acidification and, conversely, how acidification may indirectly influence the outcome of these interactions. To date, few studies have investigated how competition and facilitation between coral reef benthic taxa may function in the future. Our results add to this limited knowledge by showing no interactive effects of acidification and direct contact on growth on representative coral, algal, and sponge species in the Florida Keys. While limited in scope due to the experimental design, our results also lend support to the hypothesis of transitions to sponge and algae dominated reefs in the future [4] through facilitation of algal growth by sponges and direct effect of acidification on sponge growth. Additional research on the outcome of species interactions under climate change will facilitate accurate predictions of how coral reefs may respond to environmental changes and identification of appropriate reef management strategies and policies for the Florida Reef Tract.

Supplementary Materials: The following are available online at https://www.mdpi.com/article/ 10.3390/jmse9070739/s1, Figure S1: Photographs showing an experimental set-up of interaction treatments. Table S1: Buoyant weight of corals, wet weight of algae, and biovolumes of sponges at the beginning and end of the experiment. Table S2: Seawater chemistry data measured in reservoir tanks and experimental aquaria. Temperature and Salinity were measured daily using a YSI multiprobe. Seawater samples for dissolved inorganic carbon (DIC) and total alkalinity (TA) were collected weekly for later laboratory analyses.

Author Contributions: Conceptualization, H.N.P.; methodology, H.N.P., C.H., and H.T.; formal analysis, H.N.P., C.H., H.T., and E.R.H.; writing—original draft preparation, H.N.P.; writing—review and editing, H.N.P., C.H., H.T., and E.R.H.; visualization, H.N.P.; supervision, E.R.H.; project administration, H.N.P.; funding acquisition, H.N.P. All authors have read and agreed to the published version of the manuscript.

Funding: This work was supported by Mote Marine Laboratory's Postdoctoral Research Fellowship (HNP).

Institutional Review Board Statement: Not applicable.

Informed Consent Statement: Not applicable.

Data Availability Statement: The data presented in this study are available in Supplemental Tables S1 and S2.

Acknowledgments: We would like to thank Emily Hower, Lindsay Arick, and Ocean Acidification Program interns at Mote Marine Laboratory for assistance with setting up and maintaining the experiment.

Conflicts of Interest: The authors declare no conflict of interest.

\section{References}

1. Bindoff, N.L.; Cheung, W.W.L.; Kairo, J.G.; Arístegui, J.; Guinder, V.A.; Hallberg, R.; Hilmi, N.; Jiao, N.; Karim, M.S.; Levin, L.; et al. Changing ocean, marine ecosystems, and dependent communities. In IPCC Special Report on the Ocean and Cryosphere in a Changing Climate; Pörtner, H.-O., Roberts, D.C., Masson-Delmotte, V., Zhai, P., Tignor, M., Poloczanska, E., Mintenbeck, K., Alegría, A., Nicolai, M., Okem, A., et al., Eds.; IPCC: Geneva, Switzerland, 2019; in press.

2. Cai, W.-J.; Hu, X.; Huang, W.-J.; Murrell, M.C.; Lehrter, J.C.; Lohrenz, S.E.; Chou, W.-C.; Zhai, W.-D.; Hollibaugh, J.T.; Wang, Y.; et al. Acidification of subsurface coastal waters enhanced by eutrophication. Nat. Geosci. 2011, 4, 766-770. [CrossRef]

3. Andersson, A.J.; MacKenzie, F.T. Revisiting four scientific debates in ocean acidification research. Biogeosciences 2012,9 , 893-905. [CrossRef]

4. Bell, J.J.; Davy, S.; Jones, T.; Taylor, M.W.; Webster, N. Could some coral reefs become sponge reefs as our climate changes? Glob. Chang. Biol. 2013, 19, 2613-2624. [CrossRef] [PubMed]

5. Chan, N.C.S.; Connolly, S.R. Sensitivity of coral calcification to ocean acidification: A meta-analysis. Glob. Chang. Biol. 2013, 19, 282-290. [CrossRef]

6. Fang, J.K.H.; Mello-Athayde, M.A.; Schönberg, C.H.L.; Kline, D.; Hoegh-Guldberg, O.; Dove, S. Sponge biomass and bioerosion rates increase under ocean warming and acidification. Glob. Chang. Biol. 2013, 19, 3581-3591. [CrossRef] [PubMed] 
7. Koch, M.; Bowes, G.; Ross, C.; Zhang, X.-H. Climate change and ocean acidification effects on seagrasses and marine macroalgae. Glob. Chang. Biol. 2013, 19, 103-132. [CrossRef] [PubMed]

8. Johnson, M.D.; Price, N.; Smith, J.E. Contrasting effects of ocean acidification on tropical fleshy and calcareous algae. PeerJ 2014, 2, e411. [CrossRef]

9. Bennett, H.M.; Altenrath, C.; Woods, L.; Davy, S.K.; Webster, N.S.; Bell, J.J. Interactive effects of temperature and $\mathrm{pCO}_{2}$ on sponges: From the cradle to the grave. Glob. Chang. Biol. 2017, 23, 2031-2046. [CrossRef]

10. Edmunds, P.J.; Comeau, S.; Lantz, C.; Andersson, A.; Briggs, C.; Cohen, A.; Gattuso, J.-P.; Grady, J.M.; Gross, K.; Johnson, M.; et al. Integrating the effects of ocean acidification across functional scales on tropical coral reefs. BioScience 2016, 66, 350-362. [CrossRef]

11. Diaz-Pulido, G.; Gouezo, M.; Tilbrook, B.; Dove, S.; Anthony, K. High $\mathrm{CO}_{2}$ enhances the competitive strength of seaweeds over corals. Ecol. Lett. 2010, 14, 156-162. [CrossRef] [PubMed]

12. Del Monaco, C.; Hay, M.E.; Gartrell, P.; Mumby, P.; Diaz-Pulido, G. Effects of ocean acidification on the potency of macroalgal allelopathy to a common coral. Sci. Rep. 2017, 7, srep41053. [CrossRef] [PubMed]

13. Campbell, J.E.; Sneed, J.M.; Johnston, L.; Paul, V.J. Effects of ocean acidification and contact with the brown alga Stypopodium zonale on the settlement and early survival of the coral Porites astreoides. Mar. Ecol. Prog. Ser. 2017, 577, 67-77. [CrossRef]

14. McCook, L.; Jompa, J.; Diaz-Pulido, G. Competition between corals and algae on coral reefs: A review of evidence and mechanisms. Coral Reefs 2001, 19, 400-417. [CrossRef]

15. Bell, J.J. The functional roles of marine sponges. Estuar Coast. Shelf Sci. 2008, 79, 341-353. [CrossRef]

16. Pawlik, J.R.; Burkepile, D.E.; Thurber, R.V. A vicious cycle? Altered carbon and nutrient cycling may explain the low resilience of Caribbean coral reefs. BioScience 2016, 66, 470-476. [CrossRef]

17. De Goeij, J.; Van Oevelen, D.; Vermeij, M.J.A.; Osinga, R.; Middelburg, J.; De Goeij, A.F.P.M.; Admiraal, W. Surviving in a marine desert: The sponge loop retains resources within coral reefs. Science 2013, 342, 108-110. [CrossRef] [PubMed]

18. Rix, L.; de Goeij, J.; Mueller, C.E.; Struck, U.; Middelburg, J.; Van Duyl, F.C.; Al-Horani, F.A.; Wild, C.; Naumann, M.S.; Van Oevelen, D. Coral mucous fuels the sponge loop in warm- and cold-water coral reef ecosystems. Sci. Rep. 2016, 6, 18715. [CrossRef]

19. Campana, S.; Hudspith, M.; Lankes, D.; De Kluijver, A.; Demey, C.; Schoorl, J.; Absalah, S.; Van der Meer, M.T.J.; Mueller, B.; De Goeij, J.M. Processing of naturally sourced macroalgal- and coral-dissolved organic matter (DOM) by high and low microbial abundance encrusting sponges. Front. Mar. Sci. 2021, 8, 640583. [CrossRef]

20. Rix, L.; De Goeij, J.; Van Oevelen, D.; Struck, U.; Al-Horani, F.A.; Wild, C.; Naumann, M. Reef sponges facilitate the transfer of coral-derived organic matter to their associated fauna via the sponge loop. Mar. Ecol. Prog. Ser. 2018, 589, 85-96. [CrossRef]

21. McMurray, S.; Stubler, A.; Erwin, P.; Finelli, C.; Pawlik, J. A test of the sponge-loop hypothesis for emergent Caribbean reef sponges. Mar. Ecol. Prog. Ser. 2018, 588, 1-14. [CrossRef]

22. Diaz, M.C.; Ward, B.B. Sponge-mediated nitrification in tropical benthic communities. Mar. Ecol. Prog. Ser. 1997, 156, 97-107. [CrossRef]

23. Southwell, M.W.; Weisz, J.B.; Martens, C.S.; Lindquist, N. In situ fluxes of dissolved inorganic nitrogen from the sponge community on Conch Reef, Key Largo, Florida. Limnol. Oceanogr. 2008, 53, 986-996. [CrossRef]

24. Silbiger, N.J. Impacts of Sponge Produced Dissolved Inorganic Nitrogen on Caribbean Coral Reef Seaweed Communities. Master's Thesis, University of North Carolina at Chapel Hill, Chapel Hill, NC, USA, 2009. [CrossRef]

25. Smith, J.E.; Shaw, M.; Edwards, R.A.; Obura, D.; Pantos, O.; Sala, E.; Sandin, S.A.; Smriga, S.; Hatay, M.; Rohwer, F.L. Indirect effects of algae on coral: Algae-mediated, microbe-induced coral mortality. Ecol. Lett. 2006, 9, 835-845. [CrossRef] [PubMed]

26. Barott, K.L.; Rohwer, F.L. Unseen players shape benthic competition on coral reefs. Trends Microbiol. 2012, 20, 621-628. [CrossRef]

27. Aerts, L.A.M. Sponge/coral interactiosn in Caribbean reefs: Analysis of overgrowth patterns in relation to species identity and cover. Mar. Ecol. Prog. Ser. 1998, 175, 241-249. [CrossRef]

28. Glynn, P.W.; Manzello, D.P. Bioerosion and coral reef growth: A dynamic balance. In Coral Reefs in the Anthropocene; Birkeland, C., Ed.; Springer: Dordrecht, The Netherlands, 2015. [CrossRef]

29. Loh, T.-L.; McMurray, S.E.; Henkel, T.P.; Vicente, J.; Pawlik, J.R. Indirect effects of overfishing on Caribbean reefs: Sponges overgrow reef-building corals. PeerJ 2015, 3, e901. [CrossRef]

30. Wisshak, M.; Schönberg, C.H.L.; Form, A.; Freiwald, A. Ocean acidification accelerates reef bioerosion. PLoS ONE 2012, 7, e45124. [CrossRef]

31. González-Rivero, M.; Yakob, L.; Mumby, P.J. The role of sponge competition on coral reef alternative steady states. Ecol. Model. 2011, 222, 1847-1853. [CrossRef]

32. Gardner, T.A.; Côté, I.M.; Gill, J.A.; Grant, A.; Watkinson, A.R. Long-term region-wide declines in Caribbean corals. Science 2003, 301, 958-960. [CrossRef]

33. Schutte, V.G.W.; Selig, E.R.; Bruno, J.F. Regional spatio-temporal trends in Caribbean coral reef benthic communities. Mar. Ecol. Prog. Ser. 2010, 402, 115-122. [CrossRef]

34. Aronson, R.B.; Precht, W.F. Conservation, precaution, and Caribbean reefs. Coral Reefs 2006, 25, 441-450. [CrossRef]

35. Lirman, D.; Manzello, D.; Maciá, S. Back from the dead: The resilience of Siderastrea radians to severe stress. Coral Reefs 2002, 21, 291-292. [CrossRef] 
36. Chartrand, K.M.; Durako, M.J.; Blum, J.E. Effect of hyposalinity on the photophysiology of Siderastrea radians. Mar. Biol. 2009, 156, 1691-1702. [CrossRef]

37. Muller, E.M.; Sartor, C.; Alcaraz, N.I.; Van Woesik, R. Spatial epidemiology of the stony-coral-tissue-loss disease in Florida. Front. Mar. Sci. 2020, 7, 63. [CrossRef]

38. Edmunds, P.J. Zooplanktivory ameliorates the effects of ocean acidification on the reef coral Porites spp. Limnol. Oceanogr. 2011, 56, 2402-2410. [CrossRef]

39. Brown, N.E.M.; Bernhardt, J.R.; Anderson, K.M.; Harley, C.D.G. Increased food supply mitigates ocean acidification effects on calcification but exacerbates effects on growth. Sci. Rep. 2018, 8, 9800. [CrossRef]

40. North Pacific Marine Science Organization. Guide to Best Practices for Ocean $\mathrm{CO}_{2}$ Measurement; Dickson, A.G., Sabine, C.L., Christian, J.R., Eds.; North Pacific Marine Science Organization: Sidney, BC, Canada, 2007; p. 191.

41. Gattuso, J.-P.; Epitalon, J.-M.; Lavigne, H.; Orr, J. Seacarb: Seawater Carbonate Chemistry. R Package Version 3.2.10. Available online: http:/ /CRAN.R-project.org/package=seacarb (accessed on 1 April 2020).

42. Lueker, T.J.; Dickson, A.G.; Keeling, C.D. Ocean $\mathrm{pCO}_{2}$ calculated from dissolved inorganic carbon, alkalinity, and equations for K1 and K2: Validation based on laboratory measurements of $\mathrm{CO}_{2}$ in gas and seawater at equilibrium. Mar. Chem. 2000, 70, 105-119. [CrossRef]

43. Jokiel, P.L.; Maragos, J.E.; Franzisket, L. Coral growth: Buoyant weight technique. In Coral Reefs: Research Methods; Stoddart, D.R., Johannes, R.E., Eds.; UNESCO: Paris, France, 1978; p. 581.

44. Fox, J.; Weisberg, S. An R Companion to Applied Regression, 3rd ed.; Sage: Thousand Oaks, CA, USA, 2019. Available online: https:/ / socialsciences.mcmaster.ca/jfox/Books/Companion/ (accessed on 10 March 2020).

45. RStudio Team. RStudio: Integrated Development for R; PBC: Boston, MA, USA, 2019. Available online: http://www.rstudio.com/ (accessed on 10 March 2020).

46. Wickham, H. ggplot2: Elegant Graphics for Data Analysis; Springer: New York, NY, USA, 2016; ISBN 978-3-319-24277-4. Available online: https:/ / ggplot2.tidyverse.org (accessed on 3 March 2020).

47. Meléndez, M.; Salisbury, J.; Gledhill, D.; Langdon, C.; Morell, J.M.; Manzello, D.; Rodriguez-Abudo, S.; Musielewicz, S.; Sutton, A. Seasonal variations of carbonate chemistry at two western Atlantic coral reefs. J. Geophys. Res. Oceans 2020, $125,016108$. [CrossRef]

48. Millero, F.J.; Hiscock, W.T.; Huang, F.; Roche, M.; Zhang, J.Z. Seasonal variation of the carbonate system in Florida Bay. Bull. Mar. Sci. 2001, 68, 101-123.

49. Zhang, J.-Z.; Fischer, C.J. Carbon dynamics of Florida Bay: Spatiotemporal patterns and biological control. Environ. Sci. Technol. 2014, 48, 9161-9169. [CrossRef]

50. Enochs, I.C.; Manzello, D.P.; Jones, P.R.; Stamates, S.J.; Carsey, T.P. Seasonal carbonate chemistry dynamics on southeast Florida coral reefs: Localized acidification hotspots from navigational inlets. Front. Mar. Sci. 2019, 6, 160. [CrossRef]

51. Crook, E.D.; Potts, D.; Rebolledo-Vieyra, M.; Hernandez, L.; Paytan, A. Calcifying coral abundance near low-pH springs: Implications for future ocean acidification. Coral Reefs 2012, 31, 239-245. [CrossRef]

52. Okazaki, R.R.; Towle, E.K.; Hooidonk, R.; Mor, C.; Winter, R.N.; Piggot, A.M.; Cunning, R.; Baker, A.; Klaus, J.S.; Swart, P.K.; et al. Species-specific responses to climate change and community composition determine future calcification rates of Florida Keys reefs. Glob. Chang. Biol. 2017, 23, 1023-1035. [CrossRef] [PubMed]

53. Okazaki, R.R.; Swart, P.; Langdon, C. Stress-tolerant corals of Florida Bay are vulnerable to ocean acidification. Coral Reefs 2013, 32, 671-683. [CrossRef]

54. Rivest, E.B.; Comeau, S.; Cornwall, C.E. The role of natural variability in shaping the response of coral reef organisms to climate change. Curr. Clim. Chang. Rep. 2017, 3, 271-281. [CrossRef]

55. Schoepf, V.; Jury, C.P.; Toonen, R.J.; McCulloch, M. Coral calcification mechanisms facilitate adaptive responses to ocean acidificiation. Proc. R. Soc. B Boil. Sci. 2017, 284, 20172117. [CrossRef] [PubMed]

56. Cyronak, T.; Takeshita, Y.; Courtney, T.A.; DeCarlo, E.H.; Eyre, B.D.; Kline, D.I.; Martz, T.; Page, H.; Price, N.N.; Smith, J.; et al. Diel temperature and $\mathrm{pH}$ variability scale with depth across diverse coral reef habitats. Limnol. Oceanogr. Lett. 2020, 5, 193-203. [CrossRef]

57. Van Der Loos, L.M.; Schmid, M.; Leal, P.P.; McGraw, C.M.; Britton, D.; Revill, A.T.; Virtue, P.; Nichols, P.D.; Hurd, C.L. Responses of macroalgae to $\mathrm{CO}_{2}$ enrichment cannot be inferred solely from their inorganic carbon uptake strategy. Ecol. Evol. 2019, 9, 125-140. [CrossRef]

58. Cornwall, C.E.; Revill, A.T.; Hall-Spencer, J.M.; Milazzo, M.; Raven, J.A.; Hurd, C.L. Inorganic carbon physiology underpins macroalgal responses to elevated $\mathrm{CO}_{2}$. Sci. Rep. 2017, 7, srep46297. [CrossRef] [PubMed]

59. Platz, M.C.; Takeshita, Y.; Bartels, E.; Arias, M.E. Evaluating the potential for autonomous measurements of net community production and calcification as a tool for monitoring coral restoration. Ecol. Eng. 2020, 158, 106042. [CrossRef]

60. Asnaghi, V.; Chiantore, M.; Mangialajo, L.; Gazeau, F.; Francour, P.; Alliouane, S.; Gattuso, J.-P. Cascading effects of ocean acidification in a rocky subtidal community. PLoS ONE 2013, 8, e61978. [CrossRef]

61. Ho, M.; Carpenter, R.C. Differential growth responses to water flow and reduced pH in tropical marine macroalgae. J. Exp. Mar. Biol. Ecol. 2017, 491, 58-65. [CrossRef]

62. Diaz, M.C.; Rütler, K. Sponges: An essential component of Caribbean coral reefs. Bull. Mar. Sci. 2001, 69, 535-546. 
63. Bell, J.J.; Bennett, H.M.; Rovellini, A.; Webster, N.S. Sponges to be winners under near-future climate scenarios. BioScience 2018, 68, 955-968. [CrossRef]

64. Duckworth, A.; West, L.; Vansach, T.; Stubler, A.; Hardt, M. Effects of water temperature and pH on growth and metabolite biosynthesis of coral reef sponges. Mar. Ecol. Prog. Ser. 2012, 462, 67-77. [CrossRef]

65. Duckworth, A.R.; Peterson, B.J. Effects of seawater temperature and $\mathrm{pH}$ on the boring rates of the sponge Cliona celata in scallop shells. Mar. Biol. 2013, 160, 27-35. [CrossRef]

66. Ribes, M.; Calvo, E.; Movilla, J.I.; Logares, R.; Coma, R.; Pelejero, C. Restructuring of the sponge microbiome favors tolerance to ocean acidification. Environ. Microbiol. Rep. 2016, 8, 536-544. [CrossRef]

67. Goodwin, C.; Rodolfo-Metalpa, R.; Picton, B.; Hall-Spencer, J. Effects of ocean acidification on sponge communities. Mar. Ecol. 2013, 35, 41-49. [CrossRef]

68. Morrow, K.M.; Bourne, D.G.; Humphrey, C.; Botté, E.S.; Laffy, P.; Zaneveld, J.; Uthicke, S.; E Fabricius, K.; Webster, N.S. Natural volcanic $\mathrm{CO}_{2}$ seeps reveal future trajectories for host-microbial associations in corals and sponges. ISME J. 2015, 9, 894-908. [CrossRef]

69. Kandler, N.M.; Wahab, M.A.A.; Noonan, S.H.; Bell, J.J.; Davy, S.K.; Webster, N.S.; Luter, H.M. In situ responses of the sponge microbiome to ocean acidification. FEMS Microbiol. Ecol. 2018, 94, 205. [CrossRef]

70. Lesser, M.P.; Fiore, C.; Slattery, M.; Zaneveld, J. Climate change stressors destabilize the microbiome of the Caribbean barrel sponge, Xestospongia muta. J. Exp. Mar. Biol. Ecol. 2016, 475, 11-18. [CrossRef]

71. Bennett, H.; Bell, J.J.; Davy, S.K.; Webster, N.S.; Francis, D.S. Elucidating the sponge stress response; lipids and fatty acids can facilitate survival under future climate scenarios. Glob. Chang. Biol. 2018, 24, 3130-3144. [CrossRef]

72. Achlatis, M.; Van Der Zande, R.M.; Schönberg, C.H.L.; Fang, J.K.H.; Hoegh-Guldberg, O.; Dove, S. Sponge bioerosion on changing reefs: Ocean warming poses physiological constraints to the success of a photosymbiotic excavating sponge. Sci. Rep. 2017, 7, 1-13. [CrossRef]

73. Schönberg, C.H.L.; Fang, J.K.H.; Carreiro-Silva, M.; Tribollet, A.; Wisshak, M. Bioerosion: The other ocean acidification problem. ICES J. Mar. Sci. 2017, 74, 895-925. [CrossRef]

74. Brown, K.T.; Bender-Champ, D.; Kenyon, T.M.; Rémond, C.; Hoegh-Guldberg, O.; Dove, S. Temporal effects of ocean warming and acidification on coral-algal competition. Coral Reefs 2019, 38, 297-309. [CrossRef]

75. Wisshak, M.; Schönberg, C.H.L.; Form, A.U.; Freiwald, A. Sponge bioerosion accelerated by ocean acidification across species and latitudes? Helgol. Mar. Res. 2014, 68, 253-262. [CrossRef]

76. Enochs, I.C.; Manzello, D.P.; Donham, E.; Kolodziej, G.; Okano, R.; Johnston, L.H.; Young, C.; Iguel, J.; Edwards, C.B.; Fox, M.D.; et al. Shift from coral to macroalgae dominance on a volcanically acidified reef. Nat. Clim. Chang. 2015, 5, 1083-1088. [CrossRef]

77. Webb, A.E.; Van Heuven, S.M.A.C.; De Bakker, D.M.; Van Duyl, F.C.; Reichart, G.-J.; De Nooijer, L.J. Combined effects of experimental acidification and eutrophication on reef sponge bioerosion rates. Front. Mar. Sci. 2017, 4, 311. [CrossRef]

78. Stubler, A.D.; Furman, B.T.; Peterson, B.J. Sponge erosion under acidification and warming scenarios: Differential impacts on living and dead coral. Glob. Chang. Biol. 2015, 21, 4006-4020. [CrossRef]

79. Wisshak, M.; Schönberg, C.H.L.; Form, A.U.; Freiwald, A. Effects of ocean acidification and global warming on reef bioerosionLessons from a clionaid sponge. Aquat. Biol. 2013, 19, 111-127. [CrossRef]

80. Stubler, A.D.; Furman, B.T.; Peterson, B.J. Effects of $\mathrm{pCO}_{2}$ on the interaction between an excavating sponge, Cliona varians, and a hermatypic coral, Porties furcate. Mar. Biol. 2014, 161, 1851-1859. [CrossRef]

81. McCook, L.J.; Folke, C.; Hughes, T.P.; Nyström, M.; Obura, D.; Salm, R. Ecological resilience, climate change and the Great Barrier Reef. In Climate Change and the Great Barrier Reef; Johnson, J., Marshall, P., Eds.; Great Barrier Reef Marine Park Authority: Townsville, Australia, 2007; pp. 75-96.

82. Fang, J.K.H.; Schönberg, C.H.L.; Mello-Athayde, M.A.; Achlatis, M.; Hoegh-Guldberg, O.; Dove, S. Bleaching and mortality of a photosymbiotic bioeroding sponge under future carbon dioxide emission scenarios. Oceologia 2018, 187, 25-35. [CrossRef] [PubMed]

83. Zhang, F.; Jonas, L.; Lin, H.; Hill, R.T. Microbially mediated nutrient cycles in marine sponges. FEMS Microbiol. Ecol. 2019, 95, 155. [CrossRef] [PubMed]

84. Mueller, B.; de Goeij, J.; Vermeij, M.; Mulders, Y.; Van Der Ent, E.; Ribes, M.; Van Duyl, F.C. Natural diet of coral-excavating sponges consists mainly of dissolved organic carbon (DOC). PLoS ONE 2014, 9, e90152. [CrossRef]

85. Corredor, J.E.; Wilkinson, C.R.; Vicente, V.P.; Morell, J.M.; Otero, E. Nitrate release by Caribbean reef sponges. Limnol. Oceanogr. 1988, 33, 114-120. [CrossRef] 